Türksoy, S. S. / Journal of Yasar University, 2021, 16/61, 361-377

\title{
Temel Psikolojik Gereksinimlerin Karşılanmasının Yabancı Dilde (İngilizce) İletişim Kurma İsteği Üzerindeki Rolü: Lisans Düzeyindeki Turizm Öğrencileri Üzerine Bir Değerlendirme

\author{
The Role of the Satisfaction of Basic Psychological Needs in The \\ Willingness to Communicate in Foreign Language (English): An Evaluation \\ of Undergraduate Tourism Students
}

\author{
Selcen Seda TÜRKSOY, Ege Üniversitesi, Türkiye, selcen.seda.turksoy@ege.edu.tr \\ Orcid No: 0000-0003-1842-0858
}

\begin{abstract}
Öz: Turizmde konuk ile ev sahibi arasında iletişimi sağlamada yabancı dil becerisi önemlidir. Turizm ĕgitiminde ögrencilerin gereksinim duyduğu yabancı dilin öğretilmesinde sorumluluk sahibi olan üniversitelerin uygulamada en çok zorlandıkları alanlardan birini “öğrencilerin konuşma becerisi edinmeleri” oluşturmaktadır. Bu noktada iletişim kurma isteği (IKİ), ikinci ve yabancı dil öğreniminde başarıy etkilediği varsayılan faktörlerden birisi olarak araştırılması gereken bir konudur. Bu yönüyle çalışma, turizm lisans öğrencilerinin temel psikolojik gereksinimlerinin karşılanması ile İngilizce IKẊ arasındaki ilişkinin araştırılmasına yöneliktir. Çalışma nicel araştırma yöntemi ile kurgulanmış ve veriler anket yardımıyla toplanmıştır. Temel psikolojik gereksinimler kavramı; özerklik, yeterlik ve ait olma, IKİ kavramı ise; anadili Ingilizce olanlarla IKİ, anadili Ingilizce olmayanlarla IKİ, devam edilen sınıfta IKİ boyutlarıyla ele alınmıştır. Çalışmada doğrulayıcı faktör analizi, keşfedici faktör analizi, fark analizleri (ANOVA ve t-test), korelasyon ve regresyon analizleri yapılmıştır. Çalışmanın bulgularına göre, özerklik, İngilizce IKI'ni tüm bağlamlarda olumlu yönde etkilemektedir. Yeterlik anadili Ingilizce olan ve anadili Ingilizce olmayan kişilerle IKI'nde etkili olurken ait olma ise anadili Ingilizce olmayanlar ve sını içinde IKI'ni etkilemektedir.
\end{abstract}

Anahtar Kelimeler: Özerklik, Yeterlik, Ait Olma, Yabancı Dilde İletişim Kurma İsteği, Turizm Ĕ̆itimi

JEL Sinıflandirmasi: I230, Z310, Z390

Abstact: Foreign language skills are important in establishing communication between guest and host community in tourism. Unfortunately, at universities, which are responsible for teaching the foreign language skills needed by students in tourism education, acquisition of speaking skills constitute the most challenging issue in practice. At this point, the willingness to communicate (WTC) is an issue that needs to be explored as one of the factors that are supposed to affect success in second and foreign language learning. Therefore; the study aims to investigate the relationship between the satisfaction of basic psychological needs of undergraduate tourism students and their WTC in English. In the study, quantitative research was adopted and questionnaire technique was used to collect the data. The concept of basic psychological needs are discussed in three dimensions as autonomy, competence and relatedness whereas the dimensions of WTC in English are WTC Native speakers, WTC Non-native speakers and WTC classmates. In the study, confirmatory and exploratory factor analysis, ANOVA and t-test, correlation and, regression analysis were used. According to the findings of the study, autonomy positively affects the WTC in English in all communicative contexts. While proficiency is effective in WTC Native and Non- native speakers, relatedness affects WTC non-native speakers and WTC classmates.

Keywords: Autonomy, Competence, Relatedness, WTC, Tourism Education

\section{Giriş}

JEL Classification: I230, Z310, Z390

Turizmde istihdam edilen çalışanların sahip olması beklenen temel özelliklerin arasında sektörün uluslararası doğası gereği belki de ilk sırada yabancı dil bilgisi gelmektedir. Turizm işletmelerinin faaliyet gösterdiği pazar göz önüne alındığında, kültürler arası hizmet sunumunda turist ile ev sahibi arasındaki iletişimin kurulmasında sektör çalışanlarının yabancı 
dil becerilerinin geliştirilmesinin önemi ortaya çıkmaktadır (Sindik ve Božinovic 2013). Uysal ve Seçilmiş (2019) yaptıkları çalışmada turizm fakültesi mezunları için İngilizce (yabancı dil) iletişim becerisinin çok önemli olmasına karşın bu beceriyi yeterince kullanamadıklarını belirtmişlerdir. Oysa sektörün sağladığı katma değer göz önünde bulundurulduğunda yabancı dil öğreniminin emek-yoğun özelliği ile turizm endüstrisine daha fazla değer kazandırdığ1 yadsınamaz bir gerçektir. Yabancı dil yetkinliği turizm endüstrisinde etkili ve verimli iletişimi sağlarken, destinasyon potansiyelinin artırılmasına ve ziyaretçilerin daha fazla harcama yapmasına da olanak vermektedir (Leslie ve Russell 2006). Donanımlı ve nitelikli çalışanlar müşterilere sunulan hizmetlerin algılanan kalitesini arttırmakta, müşteri memnuniyet düzeyini yükseltmekte (Haven, Tang ve Jones 2008) ve sonrasında müşterilerin destinasyona yeniden gelme olasılığını artırabilmektedir. Özellikle ev sahibi ile konuk arasında iyi ve etkili iletişim (özellikle ilk temas) müşteri deneyimini pozitif yönde etkilemektedir (Leslie ve Russell 2006).

Turizm alanyazın incelendiğinde turizm eğitimi alan öğrencilerin İngilizceye karşı tutumları (Davras ve Bulgan 2012), dil eğitiminden memnuniyet düzeyleri (Akgüz ve Gürsoy 2014), İngilizce dilinde başarısızlık nedenleri (Ayaz ve diğ. 2017), mevcut kitapların öğrencilerin dil gereksinimleri açısından durumu (Katayoon ve Davood 2014) ve müfredat oluşturma (Prachanant 2012; Al-Tarawneh ve Osam 2019) gibi konuların incelendiği görülmektedir. İkinci dil ediniminin ana bileşenlerinden biri olduğuna inanılan (İKİ) ve temel psikolojik gereksinimlerin karşılanmasının İKİ'ni nasıl yordadığı ise araştırma konusu olarak alanyazında yer almamaktadır. Oysa Ayaz ve diğerlerinin 2017 yılında yaptıkları çalışmada Turizm öğrencilerinin İngilizce dersinde başarılı olabilmeleri için daha çok ikna edilmesi ve güdülenmesi gerektiği, bunun için de öğrenciler arasında işbirliğini teşvik etme ve öğrenme özerkliği oluşturma gibi uygulamaların benimsenmesinin önemi vurgulanmıştır. Katayoon ve Davood (2014), öğrenme ve sonrasında İKİ'nde derste kullanılan materyaller kadar eğitmenin kendisi ve öğrencinin gereksinimlerinin karşılanmasının da önemli olduğunu belirtmişlerdir. Çünkü sınıf içinde başlayan İKİ mezun öğrencilerin iş hayatında da yabancı dilde iletişim kurma yetisi kazanmalarına olanak vermektedir. Bu noktada öğrencilerin temel psikolojik gereksinimlerinin karşılanması ile İngilizce İKİ arasında ilişkinin belirlenmesi önemlidir. İKİni etkileyen faktörlerin belirlenmesi turizm eğitiminde İngilizce öğretimindeki kalitenin yükseltilmesi ve turizm bölümü mezunlarının sektörde işe girme, istihdam edilme ve organizasyon içerisinde yükselmesinde önemli bir role sahiptir. 


\section{Literatür}

\section{1. Öz Belirleme Kuramı- Psikolojik Gereksinimlerin Karşılanması}

Motivasyon ve kişilik, Öz Belirleme Kuramı’nın (ÖBK) araştırma alanlarından birini oluşturmaktadır. Kuram yardımıyla motivasyonun farklı içsel ve dişsal kaynakları incelenmektedir. $\mathrm{Bu}$ içsel ve dışsal faktörler bilişsel ve toplumsal gelişmede ve bireysel farklılıklarda motivasyonun rolünü tanımlamaktadır. Birey içsel motivasyonla ilişkili olarak keşfetme, yönetme, anlama ve aktif içselleştirme eğilimi gösterirken, bütünleşme için de toplumsal normları ve düzenlemeleri özümseme eğilimine girmektedir. ÖBK, kökleşmiş gelişim sürecinin en iyi nasıl ilerlediği ve sürecin etkilenme ile etkileme biçimlerine odaklanmaktadır (Ryan ve Deci 2017). Deci ve Ryan (1985) tarafından geliştirilen ÖBK 'nda özerklik, yeterlik ve ilişkili olma olarak isimlendirilmiş üç temel gereksinimden bahsedilmektedir. İçsel motivasyon, içselleştirme ve toplumla bütünleşme için bu eğilimlerin özerklik (kişisel olarak davranışlarını başlatabilme), yeterlik (çevreyle etkili bir şekilde etkileşime girme arzusu) ve ilişkili olma (diğer önemli kişilere bağlı olma hissi arzusu) gibi temel psikolojik gereksinimlerin karşılanmasını gerektirmektedir. $\mathrm{Bu}$ durum iki faktöre bağlıdır: Bunlar, bireylerin ne kadar belirleyici olduğu ve toplumsal çevre tarafindan benimsenip zenginleştirilip zenginleştirilmediğidir (Deci ve Ryan 2002).

Öğrenmeyi teşvik edici sosyal faktörler, özerklik, yeterlik ve ilişkili olma gereksiniminin karşılanması yoluyla motivasyonu doğru yönde etkileyebilmektedir (Vallerand 1997). Yabancı dil eğitiminde bu üç psikolojik ihtiyacın karşılanması önemlidir. Öğrencilerin gerekli metabilişsel ve bilişsel strateji geliştirme becerileri ile donatılması ile sağlanan yeterlik; kendi öğrenme süreçlerine ilişkin seçim ve kararlarını vermelerine olanak verilmesi ile ortaya konan özerklik; akranları ve eğitmenleri tarafından önemsendiğini ve değer verildiğini hissetmesi ile ortaya çıkan ilişkili olma bir bütün olarak öğrencinin temel psikolojik gereksinimini karşılamaktadır. Böylece öğrencilere ilginç, teşvik edici ve özünde motive edici bir eğitim deneyimi sunulmuş olmaktadır ( $\mathrm{Hu}$ 2016). Bu nedenle, eğitmenlerin öğrencilerle nasıl etkileşimde bulundukları, öğrencilerin motivasyonu açısından önemlidir. Öğrenciler kendi öğrenmelerine ilişkin kararlar alıp, ilerlemeleriyle ilgili net geri bildirimler aldıklarında, özerklik, yeterlik ve ilişkili olma konusunda yüksek öz algıya sahip olmaktadırlar (Rahmanpanah 2017). Yabancı dil eğitiminde psikolojik gereksinimlerin karşılanması içsel motivasyonu artırırken (Carreira 2012), yabancı dilde İKİ'ni teşvik etmekte (Joe ve diğ. 2017), dil öğrenme deneyimi ile genel olarak olumlu duygular hissetmelerine yardımcı olmakta (Birdsell 2018) ve sınıf bağlılığını artırmalarına (Dincer ve diğ. 2019) neden olmaktadır. 


\subsection{Yabancı Dilde İletişim Kurma İsteği}

Yabancı dilde İKİ ile kültürleri kaynaştırma, hatta ulusları bir araya getirme konusundaki sosyal ve politik hedefler gerçekleşebilecektir (MacInteyre ve diğ. 1998). Bu noktada, özellikle turizm eğitimi alan öğrencilerin gerek sınıf içinde gerekse sınıf dışında İngilizce İKİ'nin artırılması derste başarı ile birlikte turizmde dil farklılığından kaynaklanan anlaşmazlık ve iletişim sorunlarını çözerek kültürler arası iletişimi olumlu yönde etkileyecektir. Genellikle kişilerin iletişim kurma yetkinliğine sahip olmasına karşın yabancı dilde iletişim kurmamayı tercih ettikleri görüşü yaygın olarak düşünülmektedir. Bu noktada iletişim kurma yetkinliği ile bu yeterliliği uygulamaya koyma arasında bir takım faktörlerin rol oynadığı ve dolayısıyla İKİ'nin öneminin arttığı görülmektedir (Dörnyei 2005). Kavramın ilişkili olduğu faktörlerin bilinmesi, eğitmenlerin öğrencilerin İKİ'ni destekleyecek yöntemleri geliştirmesine de yardımcı olabilmektedir (Zarrinabadi 2014). Ayrıca yabancı dilde İKİ oluşturulduğunda dil öğrenimi kolaylaşmakta, öğrenciler iletişim yoluyla dili öğrenmek için bağımsız çaba gösterebilmekte ve öğrenme fırsatlarını genişleterek sınıf dışında da öğrenme etkinliklerine dahil olabilmektedirler (Kang 2005).

Kavram ana dilde iletişim kurma davranışındaki bireysel farklılıkları açıklamak amacı ve kişilik temelli bir eğilim olduğu varsayımı ile alanyazında da yer almıştır (McCroskey ve Baer 1985). MacIntyre ve diğerleri (1998) yaptıkları araştırma ile yabancı dilde kişinin İKİ'ni etkileyebilecek dilbilimsel, iletişimsel ve sosyal psikolojik (kişilik, grup içi iklim, grup içi tutum, iletişim yetkinliği, grup motivasyonu, özgüven, vb.) değişkenleri belirlemişlerdir (MacInteyre ve diğ. 1998). Bu değişkenler yabancı dilde İKİ'ni etkilemekte, yabancı dilde İKİ de dil ediniminde başarıya yol açmaktadır. Dilin kullanılması konusunda daha aktif olan dil öğrencileri, başkalarıyla sohbet etmek için daha fazla firsat bularak, dil yeterliliğini geliştirme konusunda daha büyük bir potansiyele sahip olabilmektedir (Kim 2004). Diğer taraftan öğrencilerin uluslararası topluma karşı tutumları (Bektaş ve Çetinkaya 2007), İngilizce öğrenme motivasyonları (Asmalı 2016) ve İngilizce iletişimine duydukları güven (Asmalı 2016) bu dilde İKİ'ni etkilemektedir. Yine yapılan çalışmalarda özgüven (Kim 2004; Jung 2011), algılanan yeterlik (MacIntyre 1994), motivasyon (Jung 2011), iletişim kaygısı (MacIntyre 1994), eğitmen tutumu (Zarrinabadi 2014) ve eğitmenin kullandığı disiplin sağlama yöntemleri (Khodarahmi ve Nia 2014) ile İKİ arasında ilişki bulunduğu tespit edilmiştir.

\subsection{Temel Psikolojik Gereksinimlerin Karşılanması Ve İngilizce İKं}

Temel psikolojik gereksinimlerin karşılanması (Öz Belirleme Kuramı) motivasyon teorileri ile ilişkilendirilmektedir (Noels ve diğ. 2000; Carreira 2012). Yapılan çalışmalarda öğrencilerin 
seçme özgürlüğü ve dilde yeterlik algısında bireyin kendisi ve motivasyonun etkili olduğu görülmüştür (Noels ve diğ. 2000). Motivasyonla ilişkilendirilen temel psikolojik gereksinimlerin karşılanmasının İngilizce İKİ'ne doğrudan etkisi ise Joe ve diğerlerinin (2017) yapmış olduğu çalışma ile ölçülmüştür. Çalışmanın bulguları öğrencilerin temel psikolojik gereksinimlerinin bir bütün olarak karşılanmasının İngilizce dilinde İKİ üzerinde doğrudan etkisi olduğu yönündedir. Yine temel psikolojik gereksinimlerin boyutlarını oluşturan özerklik (Khaki 2013; Mohammadi ve Mahdivand 2019), yeterlik (MacIntyre ve Doucette 2010) ve ait olma (Cao 2011) değişkenlerinin İngilizce İKİ'ni ayrı ayrı olarak yordadığını gösteren çalışmalar da vardır. MacIntyre, Burns ve Jessome (2011) yaptıkları çalışmada öğrencilerin dilde İKİnin azaldığı ya da arttığı durumları özerklik, yeterlik ve ait olma gereksinimlerinde ortaya çıkan değişikliklerle açıklamışlardır.

Gelişen turizm hareketleriyle birlikte turizm eğitimi alan öğrencileri dil becerileri ile donatılmasının önemini vurgulayan çalışmalar incelendiğinde uygulama alanı olarak üniversitelerin turizm bölümlerinin ele alındığı bir araştırmanın yapılmadığı görülmüştür. Çalışmanın alanyazındaki boşluğu doldurmada katkısının olacağı düşünülmektedir. Öğrencilerin Temel Psikolojik gereksinimlerinin karşılanması ders içinde başlayan ve sonrasında staj, yaz tatillerinde çalışma vb. etkinliklerle ortaya çıkabilecek İngilizce İletişim Kurma firsatlarını değerlendirebilmesi açısından yararlı olacaktır.

\section{Yöntem}

Çalışmada alan araştırması yöntemi, veri toplama aracı olarak da anket tekniğinden yararlanılmıştır. Araştırma turizm eğitimi veren bir yükseköğretim kurumunda yürütülmüştür. Kurumun belirlenmesinde turizm işkolunun ana bileşenlerine yönelik üç temel bölümünün olması ve farklı puan dilimlerinden öğrenci kabul etmesi dikkate alınmıştır. Veri toplamada, kolayda örnekleme yöntemi kullanılmıştır. Anketler Mayıs (2018) ayında öğrencilere yüz yüze uygulanmıştır. Uygulama yapılırken anketler okulun üç farklı bölümündeki tüm öğrencileri kapsayacak biçimde öğrencilerin okulda en yoğun olarak bulundukları dönemde elden dağıtılmıştır. Dağıtılan anketlerin özellikle istekli öğrenciler tarafından doldurulmasına özen gösterilmiştir. Çalışmanın yapıldığı dönemde yüksekokulun üç bölümünde 1180 öğrenci kayıtlı olduğu belirtilmiştir. Dağıtılan, ancak eksik işaretlemeler nedeni ile değerlendirmeye alınmamış 25 anket geçersiz olarak kabul edilmiş ve değerlendirmeye 338 anket dahil edilmiştir. Örneklem büyüklüğünün hesaplanmasında Krejcie ve Morgan (1970) tarafından örnekleme hatası, güven düzeyi ve oranları esas alınarak oluşturulan tabloya göre değerlendirmeye alınan anket sayısı evreni temsil etmektedir ve yeterlidir. 
Araştırmada kullanılan anket toplam üç bölümden oluşmaktadır. Giriş kısmında anketin yapılış amacı, hangi kurum için neden yapıldığı ve sonuçlarının hangi çerçevede değerlendirileceğine ilişkin bilgiler yer almaktadır. Birinci ve ikinci bölümde ölçeklere ilişkin ifadeler, son bölümde ise demografik sorulara yer verilmiştir. Araştırmadaki değişkenlerin ölçümünde Joe ve diğerlerinin (2017) çalışmasında kullandığı Temel Psikolojik İhtiyaçlar ölçeği (Cronbach's alpha = ,81 / ,78 / ,71) ile Baghaei ve diğerlerin (2012) katılımcıların farklı koşullar altında, farklı bağlamlarda ve farklı kişilerle iletişimi başlatmaya hazır olduklarına ilişkin İletişim Kurma İsteği Ölçeği'nden (Cronbach’s alpha = ,66 / ,79 / 68 / ,78) yararlanılmıştır. Temel Psikolojik Gereksinimler Ölçeği; Özerklik, Yeterlik, Ait olma boyutları ile dokuz ifade, Yabancı Dilde İletişim Kurma İsteği Ölçeği; Anadili İngilizce olanlar, Anadili Ingilizce olmayanlar, sınıftakilerle boyutları ile 20 ifadeden oluşmaktadır. Kullanılan ifadeler beşli Likert ölçeği (Kesinlikle katılmıyorum-Kesinlikle katılıyorum) ile değerlendirilmiştir. Araştırmada kullanılan ölçeklerdeki ifadeler bir dilbilimci ve üç turizm akademisyeni tarafindan değerlendirilmiştir. Ölçeğin çevirisinde geleneksel yaklaşım kullanılarak ifadeler öncelikle İngilizce'den Türkçe'ye çevrilmiş, sonra ters çeviri yapılmıştır (Hançer, 2003). Oluşturulan ölçekteki ifadelerin net ve anlaşılabilir olduğu konusunda fikir birliğine varılmıştır. Araştırmada uygulanacak anketin oluşturulmasından sonra her iki dili de konuşan 40 katılımcı ile pilot test yapılmıştır. Test çalışmasında Temel Psikolojik Gereksinimler ölçeğinin güvenirliği $(\alpha=, 83)$ ve İletişim Kurma İsteği ölçeğinin güvenirliği $(\alpha=, 83)$ bulunmuştur. İfadelerin basıklık $(-1,353-+0.270)$ ve çarpıklık değerlerine $(-1.057-+0.333)$ bakıldığında değerlerin normal dağılım gösterdiği görülmüş (Tabachnick ve Fidell 2013) ve verilerin analizinde parametrik testler kullanılmıştır. Analizde, ölçeklerin ülkemizdeki yapı geçerliliğini belirlemek için doğrulayıcı ve keşfedici faktör analizi, fark analizine ilişkin t-testi ile ANOVA ve değişkenler arasındaki ilişkileri belirlemek için ise korelasyon analizi kullanılmıştır. Boyutlar arasındaki etkinin yönü için regresyon analizinden yararlanılmıştır.

\section{Analiz ve Bulgular}

Araştırmaya üç bölümden toplam 338 öğrenci katılmıştır. Öğrencilerin demografik bilgilerine ilişkin veriler değerlendirildiğinde \% 44'ü Konaklama İşletmeciliği, \% 32'si Turizm Rehberliği, kalan \% 21'i de Seyahat İşletmeciliği bölümüne kayıtlıdır. Öğrencilerin 91'i üçüncü, 90'1 dördüncü, 51'i ikinci ve 37'si de birinci sınıf öğrencisidir. Öğrencilerin \% 38'inin İngilizce hazırlık eğitimi aldığı, \% 26'sının da bir şekilde yurt dışında bulunduğu görülmektedir. Öğrencilerin yurt dışı deneyimi olması ve hazırlık eğitimi almaları değişkenlerin değerlendirilmesi açısından olumludur. Yürütülen çalışmada güvenilirlik analizinde ölçüt 
olarak Cronbach Alpha değeri kullanılmıştır. Ölçeklerin güvenirliğini ölçmek için Cronbach’s Alpha testi yapılmış, temel psikolojik gereksinimlerin tatmini ölçeğinin güvenirliği $\alpha=, 764$ ve İletişim Kurma İsteği ölçeğinin güvenirliği $\alpha=$,938 olarak bulunmuştur. Elde edilen sonuçlara göre kullanılan ölçekler güvenilirdir (Hair ve diğg. 2006). Çalışmada ölçeklerin yapı geçerliliğini sağlayıp sağlamadığını test etmek amacıyla doğrulayıcı faktör analizi yapılmıştır.

Temel psikolojik gereksinimleri tatmini ölçeğine ilişkin doğrulayıcı faktör analizi standardize değerleri ve $t$ değerleri Şekil 1'de yer almaktadır. Bu değerlerin 1'in üzerinde olmaması ve $t$ değerlerinin ise en az 1,96 (0,05 düzeyinde) olması gerekmektedir (Hair ve diğ. 2006). $T$ değerleri ve standardize değerler incelendiğinde, geliştirilen ölçeğe ilişkin ölçme modeli kabul edilebilir düzeydedir. Ölçme modelinin bütün olarak kabul edilebilmesi için gerekli uyum indeksi değerlerinin de (goodness-of-fit statistics) de istenilen düzeyde olması gerekmektedir.
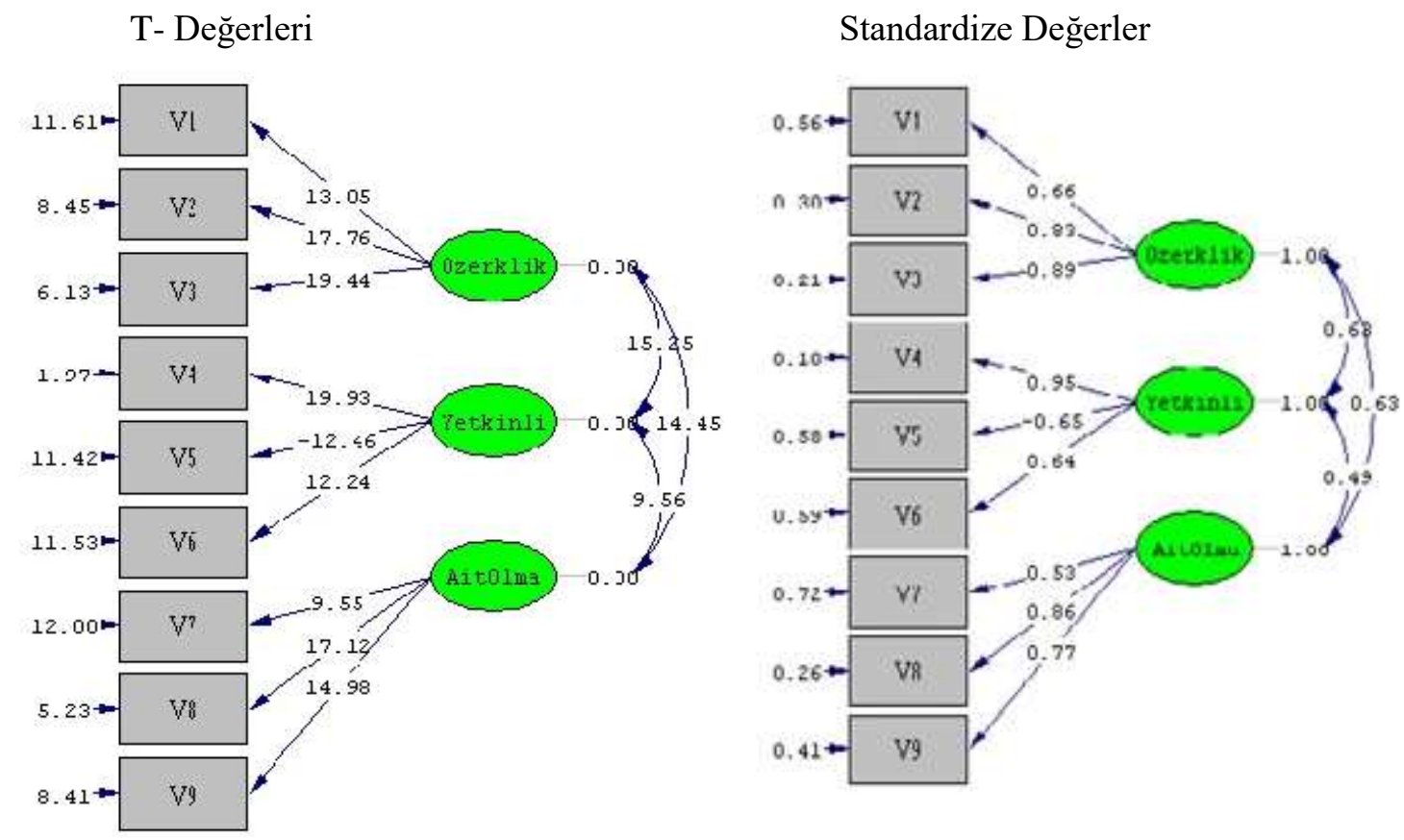

Şekil 1. Yol Şemasında T- Değerleri ve Hata Varyanslarının İncelenmesi

Modele ait uyum indeksleri incelendiğinde serbestlik derecesinin 24, $x^{2}$ nin de 102,57 olduğu görülmektedir. Normalleştirilmiş $x^{2}$ değeri ise ( $\left.x^{2} / \mathrm{df}\right) 4,27^{\prime}$ dir. Bu değerin 2 ila 5 arası olması kabul edilebilir düzeyi ifade etmektedir (Hair ve di

RMSEA'nın \%5'in altında çıkması ise modelin mükemmel uyum gösterdiğini (Brown, 2006), \%10’un altında çıkması ise zayıf ancak kabul edilebilir bir model (Tabachnick ve Fidell 2001) olarak yorumlanmasına olanak sağlamaktadır. Modele ilişkin RMSEA değeri 0,09 bulunmuştur. Model kabul edilebilir sınırlardadır. Diğer uyum indeksleri incelendiğinde 
CFI'nın 0,96 NFI'nin 0,95 olması (Tabachnick ve Fidell 2001); GFI nin 0,94 (Schumacker ve Lomax 1996), AGFI'nin 0,88 olması modelin kabul edilebilir olmasında yeterli görülmektedir. Temel Psikolojik Gereksinimler Değişkenine ilişkin doğrulayıcı faktör analizi sonuçları incelendiğinde, kurama dayalı olarak özerklik, yeterlik ve ait olma boyutlarından oluşan yapı farklı bir dilde doğrulanmıştır.

Yabancı Dilde İletişim Kurma İsteği Ölçeği'ne ilişkin doğrulayıcı faktör analizi $t$ değerleri ve standardize değerleri Şekil 2'de yer almaktadır. Modeldeki $t$ değerleri ve standardize değerler incelendiğinde, $t$ değerlerinin 1.96'nın üzerinde olduğu ve V16 (0.94) değişkeninin hata varyansının yüksek olduğu görülmektedir. Ancak $t$ değerinin anlamlı bulunması nedeniyle bu göstergelerin modelde kalmasına karar verilmiştir (Çokluk ve diğ. 2012). Modele ait uyum indeksleri incelendiğinde serbestlik derecesinin $165, x^{2}$ nin de 1219.88 olduğu görülmektedir. Normalleştirilmiş $x^{2}$ değeri ise ( $\left.x^{2} / \mathrm{df}\right)$ 7,39'dir. Bu değerin 2 ila 5 arası olması kabul edilebilir düzeyi ifade ettiğinden zayıf uyumu göstermektedir (Hair ve diğ. 2006).
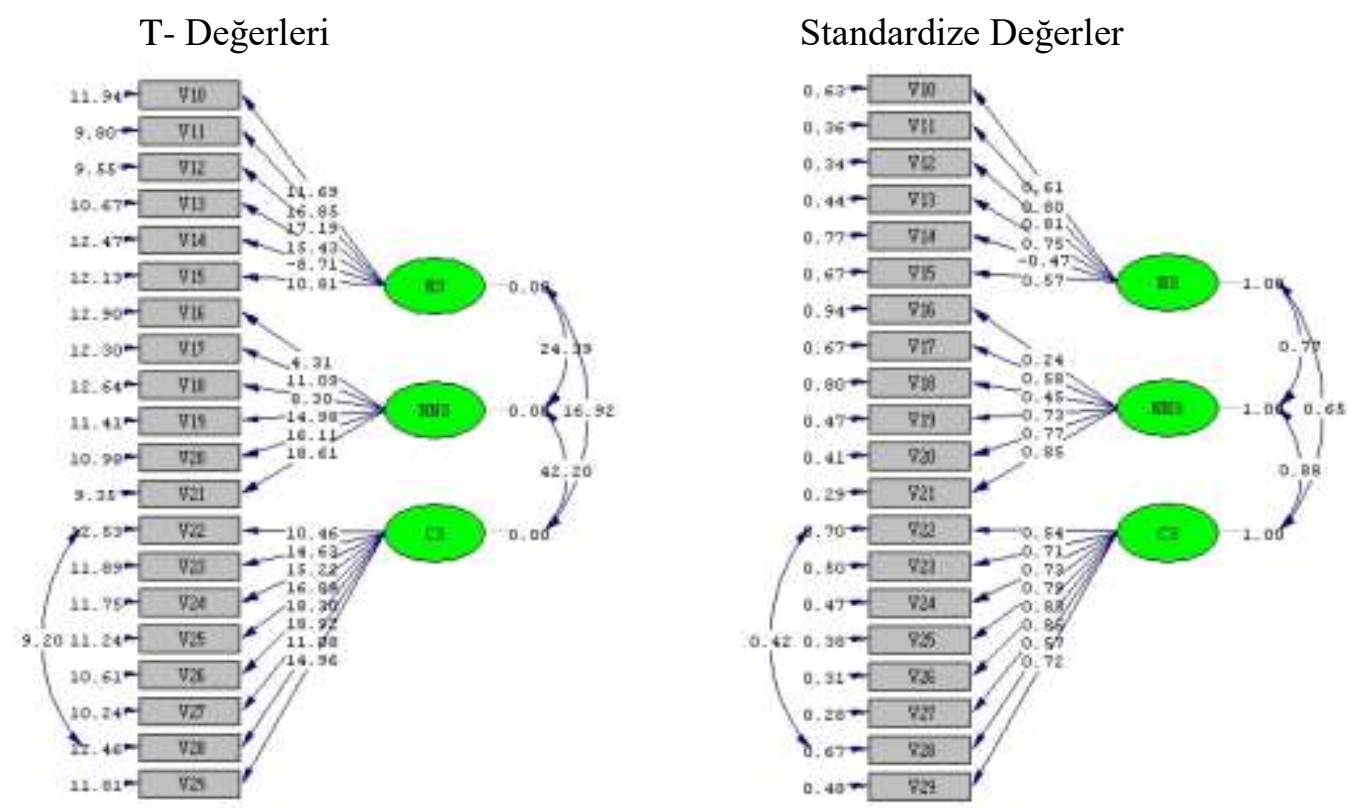

Şekil 2. Yol Şemasında T- Değerleri ve Hata Varyanslarının İncelenmesi

Model için RMSEA değeri 0,13 bulunmuştur. Değer kabul edilebilir sınırların dışındadır. Diğer uyum indeksleri incelendiğinde CFI'nın 0,91 NFI'nin 0,89 olmas1; GFI nin 0,70, AGFI'nin 0,62 olması uyum indekslerinin zayıflığını göstermektedir. Bu noktada model doğrulanmadığı için keşfedici faktör analizi ile faktör deseninin keşfedilmesi yoluna gidilmiştir (Suhr 2006, Çokluk ve diğ. 2012). İfadeler orijinal ölçekten farklı olarak turistlerle iletişim kurma isteğini ölçmek üzere uyarlandığı için öğrencilerin yanıtlarının faktör yapısını nasıl 
oluşturduğunu belirlemek de önemlidir. Böylelikle ülkemiz kültüründe ve farklı bir uygulama alanında kurama ilişkin temel bilgiye ulaşılması amaçlanmıştır.

Tablo 1. Yabancı Dilde İletişim Kurma İsteği Ölçeği Faktör Analizi

\begin{tabular}{|c|c|c|c|c|c|c|}
\hline & Faktör & Ortalama & Özdeğer & Açıklanan & $\alpha$ & $P$ \\
\hline & Değeri & & & Varyans & & \\
\hline Faktör 1: Anadili İngilizce Olanlarla İletişim Kurma İsteği & & 3,9769 & 4,735 & 29,593 & ,886 & ,000 \\
\hline $\begin{array}{l}\text { Ana dili İngilizce olan turistlerle karşılaşırsam (restoran, otel } \\
\text { veya sokakta) umarım bir firsat doğar ve onlar benimle } \\
\text { konuşurlar. }\end{array}$ & ,816 & & & & & \\
\hline $\begin{array}{l}\text { Ana dilli İngilizce olan turistler Türkçe bilmediği için sorun } \\
\text { yaşarlarsa bu firsatı değerlendirip onlarla konuşurum. }\end{array}$ &, 805 & & & & & \\
\hline Ana dili İngilizce olan turistlerle konuşmaya hevesliyimdir. & ,759 & & & & & \\
\hline $\begin{array}{l}\text { Eğer birisi beni ana dili İngilizce olan bir turistle tanıştırırsa } \\
\text { kendisiyle iletişim kurmak için elimden geleni yaparım. }\end{array}$ &, 751 & & & & & \\
\hline Faktör 2 Anadili İngilizce Olmayanlarla İletişim Kurma İsteği & & 3,2371 & 3,323 & 20,770 & ,861 & ,000 \\
\hline Ana dili İngilizce olmayan turistlerle konuşmaya hevesliyimdir. & ,836 & & & & & \\
\hline $\begin{array}{l}\text { Anadili İngilizce olmayan turistlerle ilginç deneyimlerini } \\
\text { paylaşmak isterim. }\end{array}$ &, 760 & & & & & \\
\hline $\begin{array}{l}\text { Ana dili İngilizce olmayan turistlere eşlik etmeye ve bir gün } \\
\text { ücretsiz olarak tur rehberi olmaya razıyım. }\end{array}$ & ,747 & & & & & \\
\hline $\begin{array}{l}\text { Ana dili İngilizce olmayan turistlerle sokakta, restoranlarda, } \\
\text { otellerde vs. karşılaşırsam bir mazeret bulur ve onlarla } \\
\text { konuşurum. }\end{array}$ & ,707 & & & & & \\
\hline Faktör 3: Sınıftakilerle İletişim Kurma İsteği & & 3,2339 & 3,011 & 18,821 & ,916 & ,000 \\
\hline Sınıf arkadaşlarıma karşı İngilizce sunum yapmaya hazırım. & ,765 & & & & & \\
\hline $\begin{array}{l}\text { İngilizce konuşmak için sınıfın dışında hocalarımla İngilizce } \\
\text { konuşmaya razıyım. }\end{array}$ & ,752 & & & & & \\
\hline $\begin{array}{l}\text { Sınıftaki grup çalışması aktivitelerinde grup arkadaşlarımdan } \\
\text { oluşmasa da İngilizce konuşmaya hazırım. }\end{array}$ & ,743 & & & & & \\
\hline $\begin{array}{l}\text { Sınıfımda çifte ve grup etkinliklerine katılıyorum. Böylece sınıf } \\
\text { arkadaşlarımla İngilizce konuşabilirim. }\end{array}$ & ,742 & & & & & \\
\hline $\begin{array}{l}\text { Üniversitede aldığım derslerde İngilizce sorular sormaya } \\
\text { hazırım. }\end{array}$ & ,729 & & & & & \\
\hline $\begin{array}{l}\text { Sınıftaki grup çalışması etkinliklerinde grup arkadaşlarımdan } \\
\text { oluştuğu takdirde İngilizce konuşmaya hazırım. }\end{array}$ &, 724 & & & & & \\
\hline $\begin{array}{l}\text { Sinıf arkadaşlarım beni dinlerken sınıfta İngilizce konuşmak ve } \\
\text { fikirlerimi ifade etmek isterim. }\end{array}$ &, 715 & & & & & \\
\hline $\begin{array}{l}\text { İngilizcemi geliştirmek için sınıfın dışında sınıf arkadaşlarımla } \\
\text { İngilizce konuşmaya hazırım. }\end{array}$ &, 554 & & & & & \\
\hline
\end{tabular}

Faktör Çıkarma Yöntemi: Temel Bileşenler Döndürme Yöntemi Varimax

Kaiser-Meyer-Olkin Örneklem Yeterliliği $=.935(\mathrm{p}<0.001)$

Bartlett Küresellik testi için $x^{2}=3266.118$

Açıklanan Toplam Varyans $=69.184$

Ölçeğin Tamamı İçin Güvenilirlik Katsayısı = .938 
Tablo 1'deki İngilizce İKİ değişkenine ilişkin faktör analizi sonuçları incelendiğinde, orijinal ölçekteki gibi üç boyut altında oluştuğu görülmektedir. Boyutlar; anadili İngilizce olanlar, anadili İngilizce olmayanlar ve sınıftakilerle İKİ şeklinde oluşmaktadır. Ölçekte çapraz faktör yüküne sahip birinci boyutta iki ve ikinci boyutta iki ifade olmak üzere toplam dört ifade ölçekten çıkarılmıştır (Hair ve diğ. 2006). Ölçekte yer alan ifadeler değişkeninin \% 69,18'ini açıklamaktadır. Öğrencilerin anadili İngilizce olan turistlerle İKİ boyutuna "katıllyorum" a yakın değerlendirme yaptıkları gözlenmiştir. Diğer iki boyutta ortalama değer ise "ne katılıyorum ne katılmıyorum" şeklindedir.

Tablo 2. Korelasyon Analizi Tablosu

\begin{tabular}{lcccccc}
\hline & Özerklik & Yeterlik & Ait Olma & ADIOIKI & ADIOMIKI & SFIKI \\
\hline Özerklik & 1 & & & & & \\
Yeterlik &, $499^{* *}$ & 1 & & & & \\
Ait Olma &, $529^{* *}$ &, $484^{* *}$ & 1 & & & \\
ADİOIKİ &, $532^{* *}$ &, $397^{* *}$ &, $366^{* *}$ & 1 & & \\
ADİOMIKİ &, $450^{* *}$ &, $277^{* *}$ &, $392^{* *}$ &, $575^{* *}$ & 1 & \\
SFİİ &, $615^{* *}$ &, $363^{* *}$ &, $488^{* *}$ &, $641^{* *}$ &, $637^{* *}$ & 1 \\
\hline
\end{tabular}

** Korelasyon ,001 düzeyinde anlamlı

ADİOIKI : : Ana Dili İngilizce Olanlarda İKI

ADİOMIKİ : : Ana Dili İngilizce Olmayanlarda İKİ

SFIKI : : Sinıftakilerde İKं

Temel Psikolojik gereksinimlerle İngilizce İKİ arasında ilişki korelasyon analizi ile test edilmiş ve bütün boyutlar arasındaki ilişki incelenmiştir. Tablo 2'te yer alan sonuçlara göre temel psikolojik gereksinimlerin tüm boyutları ile farklı koşullar altında, farklı bağlamlarda ve farklı kişilerle iletişimi başlatmaya istekli olmaları arasında olumlu yönde ilişki belirlenmiştir. Temel psikolojik gereksinimler değişkeni ile İKİ arasında en yüksek ilişki özerklik ve İKİ’nin üç boyutu arasındadır. 
Tablo 3. ANOVA ve T-Test Analiz Tablosu

\begin{tabular}{|c|c|c|c|c|c|c|}
\hline & Özerklik & Yeterlik & Ait olma & $\begin{array}{c}\text { Anadili } \\
\text { Ingilizce } \\
\text { Olanlarla } \\
\text { IKİ }\end{array}$ & $\begin{array}{c}\text { Anadili } \\
\text { Ingilizce } \\
\text { Olmayanlarla } \\
\dot{I} \text { İ }\end{array}$ & $\begin{array}{c}\text { Sinıfta } \\
\text { Ingilizce IKI }\end{array}$ \\
\hline \multicolumn{7}{|l|}{ Bölüm } \\
\hline Konaklama & 3,3557 & 3,0201 & 2,5872 & 3,8490 & 2,9592 & 3,0038 \\
\hline Seyahat & 3,4817 & 3,0653 & 2,6261 & 3,7979 & 3,2731 & 3,0890 \\
\hline Turizm Rehberliği & 3,7309 & 3,4159 & 3,3976 & 4,2852 & 3,5933 & 3,6505 \\
\hline$F$ - test & 3,380 & 14,694 & 23,246 & 8,188 & 10,314 & 12,395 \\
\hline$p$ & ,035 &, 000 &, 000 &, 000 & ,000 &, 000 \\
\hline \multicolumn{7}{|l|}{ Sinif } \\
\hline Birinci & & 3,3514 & 2,9640 & & 2,9236 & \\
\hline İkinci & & 3,2582 & 2,9346 & & 3,4433 & \\
\hline Üçüncü & & 2,9780 & 2,5256 & & 2,9469 & \\
\hline Dördüncü & & 3,2481 & 3,1185 & & 3,4657 & \\
\hline$F$-test & & 4,989 & 5,348 & & 4,570 & \\
\hline$p$ & &, 002 & ,001 & &, 001 & \\
\hline \multicolumn{7}{|l|}{ Yurt dışında } \\
\hline \multicolumn{7}{|l|}{ Bulunma } \\
\hline Evet & 3,9026 & 3,3521 & 3,2022 & 4,3670 & 3,6903 & 3,7196 \\
\hline Hayır & 3,3738 & 3,1038 & 2,7479 & 3,8592 & 3,0904 & 3,0766 \\
\hline$F$-test & 7,186 &, 046 &, 335 & 4,934 & ,702 & 1,088 \\
\hline$p$ & 000 & ,001 & ,001 & ,000 &, 000 &, 000 \\
\hline
\end{tabular}

Araştırma değişkenleri ile bölüm ve öğrencilerin okuduğu sınıf arasında anlamlı farklılık olup olmadığını gösteren tek yönlü varyans analizi sonuçları Tablo 3 'te yer almaktadır. Tablo incelendiğinde tüm değişkenler ile öğrencilerin devam ettiği bölüm arasında da anlamlı bir fark ortaya çıkmıştır. Farklılıkların hangi gruplar arasında olduğunu belirlemek için ise varyansların homojenliği varsayımının karşılandığı tüm değişkenlerinde çoklu karşılaştırma testlerinden Hochberg's GT2 (örneklem sayısı arasında çok büyük fark olması sebebiyle) kullanılmıştır. Çoklu karşılaştırma analizinde rehberlik bölümü öğrencileri özerklik değişkeninde ayrışmasa da tüm değişkenlerde en yüksek ortalamaya sahiptir. $\mathrm{Bu}$ durum rehberlik bölümü öğrencilerinin dil yeterliliği sınavı ile bölüme yerleştirmelerine bağlı olabilir. Yeterlik, ait olma, anadili İngilizce olmayanlarla İKİ öğrencinin hangi sınıfta öğrenim gördüğü durumuna bağlı olarak anlamlı bir fark göstermektedir. Değişkenlerdeki farkın kaynağını belirlemek için varyansın homojen olarak dağıldığ 1 varsayımı karşılandığından Hochberg's GT2 (örneklem sayısı arasında çok büyük fark olması sebebiyle) kullanılmıştır. 4. Sınıf öğrencilerinin ait olma 
duygularının daha yoğun karşılandığı bu duruma da öğrencilerin yükseköğrenim eğitim ve işkolu deneyimine bağlı olarak değişkenlik göstermesinin neden olduğu düşünülebilir. Temel Psikolojik Gereksinimler ve İngilizce İKİ'nin yurt dışında bulunup bulunmama durumuna göre anlamlı bir fark gösterip göstermediği t-testi ile analiz edilmiştir. Hem özerklik, yeterlik ve ait olma hem de İngilizce İKİ (anadili İngilizce olanlar, ana dili İngilizce olmayanlar ve sınıf içi) öğrencilerin yurt dişında bulunma ve bulunmama durumuna göre anlamlı bir fark göstermektedir. Özellikle yurt dışında bulunan öğrencilerin bulunmayanlara oranla anadili İngilizce olanlarla iletişim kurma isteklerinin daha fazla olduğu belirlenmiştir.

Tablo 4. Regresyon Analizi Tablosu

\begin{tabular}{|c|c|c|c|c|c|}
\hline Temel Psikolojik Ihtiyaçların & Yabancı Dilde İletişim Kurma & $B$ & Beta & $p$ & $R^{2}$ \\
\hline Karşılanması Boyutları & İsteğ $i$ & & & & \\
\hline \multirow[t]{3}{*}{ Model } & Anadili İngilizce Olanlarla İKİ & 1,782 & &, 000 & \\
\hline & Anadili İngilizce Olmayanlarla İKİ & 1,413 & & 000 & \\
\hline & Sınıfta İngilizce İKİ & ,912 & & 000 & \\
\hline \multirow[t]{3}{*}{ Özerklik } & Anadili İngilizce Olanlarla İKİ & ,355 & ,417 & ,000 & ,310 \\
\hline & Anadili İngilizce Olmayanlarla İKİ & ,331 &, 336 & 000 & \\
\hline & Sınıfta İngilizce İKİ & ,468 & ,493 & 000 & \\
\hline \multirow[t]{3}{*}{ Yeterlik } & Anadili İngilizce Olanlarla İKİ & ,240 &, 155 & ,006 & ,235 \\
\hline & Anadili İngilizce Olmayanlarla İKİ & ,006 & ,003 & ,958 & \\
\hline & Sınıfta İngilizce İKİ & 009 & 005 & ,924 & \\
\hline \multirow[t]{3}{*}{ Ait olma } & Anadili İngilizce Olanlarla İKİ & ,067 & 072 & ,202 & ,415 \\
\hline & Anadili İngilizce Olmayanlarla İKİ & ,226 & ,211 & 000 & \\
\hline & Sınıfta İngilizce İKİ & 231 & ,225 &, 000 & \\
\hline
\end{tabular}

Temel psikolojik gereksinimlerin İngilizce İletişim Kurma İsteğine etkisi regresyon analizi ile belirlenmiştir. Modelin regresyon denklemlerinde Temel psikolojik gereksinimler (x1=Özerklik, x2=Yeterlik, x3=Ait olma) ve İngilizce İletişim Kurma İsteği $(y 1=$ Anadili İngilizce olanlarla İKİ, y2= Anadili İngilizce olmayanlarla İKİ, y3= Sınıfta İngilizce İKİ) olarak belirtilmektedir. Regresyon analizi sonuçları Tablo 4'te yer almaktadır. Anadili İngilizce olanlarla İKİ boyutunu, özerklik boyutu $(p<, 001)$ ve Yeterlik $(p=, 006)$ etkilemektedir. Anadili İngilizce olanlarla İKİ'nin \% 41 'ini özerklik, \% 15'ini de yeterlik açıklamaktadır. “y1= $1,782+0,355 \times 1+0,240 \times 2$ " olarak formüle edilmektedir. Anadili İngilizce olmayanlarla İKİ'ni özerklik $(p<, 001)$ ve ait olma $(p<, 001)$ boyutları etkilemektedir. Anadili İngilizce olmayanlarla İKİ'ni özerklik boyutu \% 33, ait olma da \% 21 açıklamaktadır. Regresyon formülü “y2 = 1,413 + 0,331x1 +0,226x3”dür. Sınıf İçi İngilizce İKİ’ni özerklik $(p<, 001)$ ve ait olma 
$(p<, 001)$ etkilemekte ve değişkenin sırasıyla \% 49 ve \% 22 'sini açıklamaktadır. Regresyon formülü de "y3=0,912+0,468x 1 +0,231x3"dür. Genel olarak Temel Psikolojik Gereksinimler boyutlarının İngilizce İletişim Kurma İsteği boyutlarına etkisi olumludur.

\section{Sonuç ve Öneriler}

Çalışmada turizm eğitimi gören lisans öğrencilerinin İngilizce İKİ ve bunu etkileyen faktörler araştırılmıştır. Katılımcıların temel psikolojik gereksinimler ölçeğine verdikleri yanıtlar değerlendirildiğinde, öğrencilerin kendilerini daha özerk hissettikleri görülmüş, dilde yetkin olma ifadelerine "ne katılıyorum ne katılmıyorum"a yakın fikir bildirdiği belirlenmiştir. Ait olma boyutu öğrenciler tarafından "kısmen katılmıyorum" ile "ne katıliyorum ne katılmıyorum”a yakın çıkmıştır. Genel olarak değerlendirildiğinde öğrencilerin temel psikolojik gereksinimlerinin karşılandığı söylenebilir. Öğrencilerin yurt dışında bulunması öğrencilerin kendi isteği ile derse katılımına, kendilerini dilde daha yetkin hissetmesine, sınıf arkadaşları ve öğretmenleri ile iletişimi artırarak içinde bulundukları çevreyle daha iyi entegre olabilmelerine yardımcı olabilmektedir. Ayrıca öğrenciler son sınıfa geldiklerinde sınıftaki öğrenme ortamından daha fazla yararlanabilmektedirler. Bu öğrencilerin arkadaşları ve öğretmenleri ile geçen üç yıl boyunca kurdukları ve sürdürdükleri iletişimin kalitesinin bir sonucu olabilir. Yüksekokul bölümlerinden turist rehberliği bölümünde öğrenim gören öğrencilerin temel psikolojik gereksinimlerine daha yüksek puanlar verdikleri görülmektedir. Öğrencilerin dil puanı ile yüksekokula kabul edilmeleriyle ilgili olabilecek bu durum öğrencilerin kendilerini yabancı dilde yetkin hissetmeleri nedeniyle gönüllü olarak derse katılım düzeyini artırabilir.

Çalışmada genel olarak öğrencilerin İngilizce İKİ'nin (özellikle de anadili İngilizce olanlarla) yüksek olduğu görülmektedir. Yurt dışında bulunmuş öğrencilerin bulunmamış olanlara oranla daha fazla İKİne sahip olmaları çalışmanın diğer bir sonucudur. Bu noktada okullarda değişim programları ile öğrencilerin yurtdışına çıkışının desteklenmesi yararlı olabilecektir. $\mathrm{Bu}$ amaçla kariyer günleri etkinlikleri kapsamında Work and Travel, Camp America v.b. programların tanıtım ve duyurularının yapılması öğrencilerin teşvik edilmesine yardımcı olabilir. Turist rehberliği bölümü öğrencilerinin diğer bölümlere göre daha fazla İKİ'ne sahip olmalarına bağlı olarak turizm fakülteleri, yüksekokulları ya da meslek yüksekokulu turizm bölümlerinde giriște dil puanıyla öğrenci alımı veya yabancı dilin toplam puan içerisindeki ağırlığının artırılması çalışma kapsamında getirilebilecek bir diğer öneriyi oluşturmaktadir. 
Çalışmada temel psikolojik gereksinimlerin öğrencilerin İngilizce İKİ'ne etkisi regresyon analizi ile ölçülmüştür. Analiz sonuçlarına göre, öğrencilerin İngilizce derslerine katılma konusunda seçim yapabilme özgürlüğü bir başka ifade ile kendilerini özerk hissetmesi ve İngilizce dilinde yeterli bilgi ve beceriye sahip olduklarını düşünmeleri anadili İngilizce olanlarla İKİ'nin boyutunu olumlu yönde etkilemektedir. Bu durum MacIntyre ve Doucette (2010) in çalışmasında algılanan yeterlik ile yabancı dilde İKİ arasındaki olumlu ilişkiyi desteklemektedir. Anadili İngilizce olmayanlarla İKİ ise öğrencilerin özerk ve ait olma ihtiyacının karşılandığı algısı olumlu yönde etkilemektedir. Sınıf içi İngilizce İKİ yine öğrencilerin ders içi faaliyetlerine ilişkin kararlarını kendileri verebilmeleri ve sınıf ortamına ait olma durumları olumlu yönde etkilemektedir. İran uyruklu İngilizce öğrenen öğrenciler üzerinde yapılan bir araştırmada özerklik ve İngilizce İKİ arasında anlamlı bir ilişki olduğu sonucuna varılmıştır (Khaki 2013). Mohammadi ve Mahdivand (2019) çalışmasında öğrencilerin özerklikleri ile İngilizce iletişim kurma istekleri arasında anlamlı bir pozitif ilişki bulmuştur. Algıladıkları özerklik derecesi ne kadar yüksek olursa, İngilizce İKİ de o kadar artmaktadır. Temel psikolojik gereksinimlerin karşılanmasının İngilizce İKİ'ne doğrudan etkisi Joe ve diğerlerinin (2017) yapmış olduğu çalışma ile ölçülmüştür. Çalışmanın bulguları öğrencilerin temel psikolojik gereksinimlerinin bir bütün olarak karşılanmasının İngilizce dilinde İKİ üzerinde doğrudan etkisi olduğu yönündedir. Aynı çalışmada yeterlik ise ayrı bir değişken olarak İngilizce İKİni artırmaktadır. Bu noktada çalışma bulguları önceki çalışma sonuçlarıyla uyumlu bir özellik göstermektedir. Joe ve diğerlerinin (2017), araştırma değişkenleri arasındaki doğrudan etkiyi öğrencilerin adanmışlık sonucu gönüllü İKİ, iyi oluş ve öz-destekle ilişkilendirmektedir. Öğretmen geri bildiriminin öğrenme sürecinde yeterlik duygusunu arttırdığg ve özellikle özerkliği destekleyici bir ortamda yabancı dil öğrenen öğrencilerin dile karşı daha olumlu duygular taşıdığı görülmektedir. Yabancı dilde algılanan yüksek yeterlik öğrencilerin yabancı dilde iletişime girmeye daha istekli olmalarına yol açmaktadır (Peng ve Woodrow 2010). Bu durumda özellikle öğretmen desteğinin (hem öğrenme hem de birey olarak öğrenciler için) öneminin yüksek olduğu unutulmamalıdır. Öğrencilerin öğrenme ve başarılı olmalarına önem verildiği algısı, öğretmenlerin desteği ve ilgisi ile cesaretlendirici yaklaşımları öğrencilerin gereksinim duydukları tatmini elde etmelerine yardımcı olabilecektir (Patrick ve diğ. 2011; Joe ve diğ. 2017).

İçerik, yöntem ve performans çıktılarını seçme konusunda verilen liderlik rolü öğrencilerin öğrenme sürecini hızlandırabilir. Özgürlük ortamının oluşturulması, bunun grup çalışmaları, oyunlar vb. etkinliklerle sınıf içinde desteklenmesi, öğrencilerin yabancı dilde yetkinliğinin artırılmasına olanak vererek İngilizce İKİ'ni olumlu yönde etkileyecektir. Yukarıda açıklanan 
önerilerin uygulanması, öğrencilerin İngilizce İKİ'ni artırmak teoride dil edinim başarısını olumlu yönde etkileyecektir. Diğer taraftan turizm öğrencilerinin mezuniyet sonrası istihdam olanakları artarken işletme hizmet kalitesinin yükselmesi ve turizmin destinasyonda gelişmesi hızlanabilecektir.

Çalışmanın yalnızca turizm eğitimi verilen bir okulda uygulanmış olması çalı̧̧manın önemli bir kısıtıdır, diğer turizm fakülte ve yüksekokullarında tekrarlanması yararlı olabilecektir. Çalışmada isteyen herkesin katılabileceği kolayda örnekleme yöntemi seçilmiştir. Çalışmada evrenin sınırlarının kesin olarak belirli olmasına karşın rastlantısal örnekleme yönteminin kullanılmaması bir diğer kısıtı oluşturmaktadır. Aynı zaman öğrencilerin kişilik tipleri ve sınıf ortamı gibi durumsal etmenlerin IKİ üzerinde etkisi yeni araştırmalarda ayrıca incelenebilir. 


\section{KAYNAKÇA}

Akgöz, Erkan ve Yüksel Gürsoy. 2014. “Turizm Eğitiminde Yabancı Dil Öğrenme, İstek ve Kararlılıkları: Selçuk Üniversitesi Beyşehir Örneği”, Journal of Tourism and Gastronomy Studies 2, no. 1: 21-29.

Al-Tarawneh, Mohammednoor ve Ulkar Vanci Osam. 2019. "Tourism English Training at The Tertiary Level in Jordan: Reality and Expectations from A University Context”, Journal of Hospitality, Leisure, Sport ve Tourism Education, 24: 155-167.

Asmal1, Mehmet. 2016. "Willingness to Communicate of Foreign Language Learners in Turkish Context, Procedia", Social and Behavioral Sciences 232: 188-195.

Ayaz, Nurettin, Sibel Yalı ve Arzuhan Aydın. 2017. "Lisans Düzeyinde Turizm Eğitimi Alan Öğrencilerin İngilizce Öğrenmedeki Başarısızlık Nedenleri”, Turar Turizm ve Araştırma Dergisi 6, no. 1: 59-72.

Baghaei, Purya, Ali Dourakhshan ve Omid Salavati. 2012. "The Relationship Between Willingness to Communicate and Success in Learning English as A Foreign Language", Modern Journal of Applied Linguistics 42: 53-67.

Bektaş-Çetinkaya, Yeşim. 2007. "Turkish Students' Willingness to Communicate in English”, Dokuz Eylül University Buca Education Faculty Journal 21: 115-123

Birdsell, Brian. 2018. "Understanding Students' Psychological Needs in an English Learning Context”, Journal of Liberal Arts Development and Practices, 2.

Brown, Timothy A. 2006. Confirmatory Factor Analysis for Applied Research, New York: Guilford Press.

Cao, Yuhan. 2011. "Investigating Situational Willingness to Communicate within Second Language Classrooms from An Ecological Perspective", System, no. 39: 468-479.

Carreira, Junko Matsuzaki. 2012. "Motivational Orientations and Psychological Needs in EFL Learning Among Elementary School Students in Japan", System: An International Journal of Educational Technology and Applied Linguistics 40, no. 2: 191-202.

Çokluk, Ömay, Şekercioğlu, Güçlü ve Şener Büyüköztürk. 2012. Sosyal Bilimler Iç̧in Çok Değişkenli Istatistik:SPSS ve Lisrel Uygulamalart. Ankara: Pegem.

Davras, Gonca M. ve Gülay Bulgan. 2012. "MYO Öğrencilerinin İngilizce Hazırlık Eğitimine Yönelik Tutumları: Isparta MYO Turizm ve Otel İşletmeciliği Örneği”, Doğuş Üniversitesi Dergisi 13, no. 2: 227-238.

Deci, Edward L. ve Richard M. Ryan. 1985. Intrinsic Motivation and Self-Determination in Human Behavior, New York: Plenum.

Deci, Edward L. ve Richard M. Ryan 2002. Handbook of Self-Determination Researc,. New York: University of Rochester Press

Dincer, Ali, Savaş Yeşilyurt, Kimberly A. Noels ve Lascano D. Vargas. 2019. "Self-Determination and Classroom Engagement of EFL Learners: A Mixed-Methods Study of the Self-System Model of Motivational Development", SAGE Operations, no. 9: 1-15.

Dörnyei, Zoltan. 2005. The Psychology Of The Language Learner, Individual Differences In Second Language Acquisition, New Jersey: Lawrence Erlbaum Associates Publishers.

Hair, Josehp H., William. B. Black, Barry Babin, Rolph E. Anderson ve Ronald L. Tatham. 2006. Multivariate Data Analysis, 6. Bask1, NJ: Pearson Prentice Hall.

Hançer, M. 2003. "Ölçeklerin Yazım Dilinden Başka Bir Dile Çevirileri ve Kullanılan Değişik Yaklaşımlar. Balıkesir Üniversitesi Sosyal Bilimler Enstitüsü Dergisi 6(10): 47-61.

Haven,Tang, Claire ve Eleri Jones. 2008. "Labour Market and Skills Needs of The Tourism and Related Sectors in Wales", International Journal of Tourism Research 10: 353-363. doi:10.1002/jtr.666

Hu, Pingying. 2016. "The Role of Basic Need Satisfaction in English Learning: A Case Study at a University in China, Linguistics and Literature Studies 4: 402-411.

Joe, Hye-Kyoung, Phil Hiver ve Ali Al-Hoorie. 2017. "Classroom Social Climate, Self-Determined Motivation, Willingness to Communicate, and Achievement: A Study of Structural Relationships in Instructed Second Language Settings", Learning and Individual Differences 53: 133-144.

Jung, Mieae. 2011. Korean EFL University Students" Willingness to Communicate in English", Yayımlanmamış Doktora Tezi, Indiana University.

Kang, Su-ja. 2005. "Dynamic Emergence of Situational Willingness to Communicate in A Second Language", System 33: 277-92.

Katayoon, Afzali ve Rezapoorian Davood. 2014. "Pragmatic Aspects of English for Tourism Course Books and ESL Learners Pragmatic Needs: A Speech Act Theory Perspective Procedia", Social and Behavioral Sciences 98: 52-59.

Khaki, Shahab. 2013. "The Relationship between Learner Autonomy and Willingness to Communicate (WTC) in Iranian EFL Learners", International Journal of Applied Linguistics and English Literature 2, no. 5: $97-$ 109.

Khodarahmi, Ensiye ve Zahra Motallebi Nia. 2014. "EFL Teachers' Classroom Discipline Strategies and Learners' Willingness to Communicate in English Inside The Classroom", Procedia - Social and Behavioral Sciences 98: 976-981. 
Kim, Seung Jung. 2004. Exploring Willingness to Communicate (WTC) in English among Korean EFL Students in Korea: WTC as A Predictor of Success in Second Language Acquisition, Yayımlanmamış Doktora Tezi, Ohio State University.

Krejcie, Robert V. ve, Daryle W. Morgan. 1970. "Determining Sample Size for Research Activities”, Educational and Psychological Measurement 30: 607-610

Leslie, David ve Hilary Russell. 2006. "The Importance of Foreign Language Skills in The Tourism Sector: A Comparative Study of Student Perceptions in The UK And Continental Europe", Tourism Management 27: 1397-1407.

MacIntyre, Peter ve Jesslyn Doucette. 2010. "Willingness to Communicate and Action Control”, System 38, no. 2: $161-171$.

MacIntyre, Peter D. 1994. "Variables Underlying Willingness to Communicate - A Causal Analysis", Communication Research Reports 11: 135-142.

MacIntyre, Peter D., Carolyn Burns ve Alison Jessome. 2011. "Ambivalence About Communicating in A Second Language: A Qualitative Study of French İmmersion Students' Willingness to Communicate”, The Modern Language Journal 95, no. 1: 81-96.

MacIntyre, Peter D., Zoltan Dörnyei, Richard Clément ve Kimberly Noels. 1998. "Conceptualizing Willingness to Communicate in A L2: A Situational Model of L2 Confidence and Affiliation”, The Modern Language Journal 82, no. 4: 545-562.

McCroskey, James. C. ve Elaine Baer. 1985. "Willingness to Communicate: The Construct and its Measurement", Annual Convention of the Speech Communication Association, Colorado.

Mohammadi, Mohammad ve Ziba Mahdivand. 2019. "Is Willingness to Communicate A Reliable Predictor of Learner Autonomy in An EFL Context? “ Center for Educational Policy Studies Journal 9, no. 1: 9-26.

Noels, Kimberly A., Luc.G. Pelletier, Richard Clément ve Robert J. Vallerand. 2000. "Why Are You Learning A Second Language? Motivational Orientations and Self- Determination Theory", Language Learning 50: 57-85. doi:10.1111/0023-8333.00111

Patrick, Helen, Avi Kaplan ve Alison Ryan M. 2011. "Positive Classroom Motivational Environments: Convergence Between Mastery Goal Structure and Classroom Social Climate", Journal of Educational Psychology 103, no. 2: 367-382.

Peng, Jian E. ve Lindy Woodrow. 2010. "Willingness to Communicate in English: A Model in The Chinese EFL Classroom Context", Language Learning 60: 834-876.

Prachanant, Nawamin. 2012. "Needs Analysis on English Language Use in Tourism Industry. Procedia", Social and Behavioral Sciences 66: 117-125.

Rahmanpanah, Hossein. 2017. "Investigating Teachers' Communicative Styles in EFL Context: A SelfDetermination Theory Perspective", Journal of Applied Linguistics and Language Research 4, no. 1: 268289.

Ryan, Richard M. ve Edward L. Deci. 2017. Self-Determination Theory Basic Psychological Needs in Motivation, Development and, Wellness-Determination Theory. New York: The Guilford Press.

Schumacker, Randall. E. ve Lomax, Richard G. 1996. A Beginner's Guide to Structural Equation Modeling. Mahwah, NJ: Lawrence Erlbaum Associates.

Sindik, Josko ve Nikolina Božinović. 2013. "Importance of Foreign Languages for A Career in Tourism As Perceived by Students in Different Years of Study", Tranzicija 15, no. 31: 16-28.

Suhr, Diana D. 2006. Exploratory or Confirmatory Factor Analysis? NC: SAS Institute.

Tabachnick, Barbara G. ve Linda S. Fidell. 2001. Using Multivariate Statistics (4th ed.), MA: Allyn \& Bacon.

Tabachnick, Barbara G. ve Linda S. Fidell. 2013. Using Multivariate Statistics (6th ed.), Boston: Allyn and Bacon

Uysal, Davud ve Cihan Seçilmiş. 2019. "English Communication Needs of Tourism Faculty Undergraduates: A Comparative Stakeholder Analysis", Journal of Tourism Leisure and Hospitality 1, no. 2: 68-75. Retrieved from https://dergipark.org.tr/en/pub/toleho/issue/51473/666739

Vallerand, Robert J. 1997. "Toward A Hierarchical Model of Intrinsic and Extrinsic Motivation”. İçinde M. P. Zanna (Editör). Advances in Experimental Social Psychology (ss. 271-360). New York: Academic Press.

Zarrinabadi, Nourollah. 2014. "Communicating in A Second Language: Investigating The Effect of Teacher on Learners" Willingness to Communicate', System 42: 288-295. 